\title{
A Dissipating Frames for Seismic Retrofitting and Building Energy-Efficiency
}

\author{
Dora Foti *, Francesco Ruggiero, Maria Francesca Sabbà $@$ and Michela Lerna \\ Department of Civil Engineering Sciences and Architecture (DICAR), Polytechnic University of Bari, \\ 70126 Bari, Italy; francesco.ruggiero@poliba.it (F.R.); mariafrancesca.sabba@poliba.it (M.F.S.); \\ michela.lerna@poliba.it (M.L.) \\ * Correspondence: dora.foti@poliba.it
}

Received: 6 July 2020; Accepted: 5 September 2020; Published: 8 September 2020

\begin{abstract}
In the present paper a new and innovative way to approach the regeneration of public buildings and public housing is proposed. It consists in a dissipative steel frame to reduce the displacement demand and to improve the energy efficiency of a real existing structure, inserting buckling-restrained axial dampers (BRAD) type dissipative braces. This system is adaptable to any construction made of reinforced concrete frames and improves energy efficiency and earthquake-resistant performance; moreover, it upgrades the aesthetics of buildings and the quality of life for the users. In fact, the system is capable of assuming different and pleasant architectural shapes offering benefits in terms of earthquake-resistant performance, energy saving, and energy production from renewable sources. The attention to the aesthetic results renders the intervention a redevelopment strategy not only on an architectural scale, but also in the urban contexts for degraded and marginalized suburbs. The performances of the proposed kit were evaluated on a case study consisting in a social house located in the south of Italy. Numerical analyses have been carried out and the results have been reported both from the seismic protection and energy efficiency points of view. As a result, the produced renewable energy from the retrofitting system and the building seismic capacity increased. A rapid and precise control process, able to return a suitable structural dimensioning of the frame, according to the different application contexts, is finally proposed.
\end{abstract}

Keywords: popular residential buildings; dissipative frames; energy efficiency; refurbishment; aesthetic improvement

\section{Introduction}

Reinforced concrete buildings built in European countries up to the 1980s, represent a significant portion of the whole building estate. Before the 1950s, these residential building stocks were designed in the absence of either energy efficiency standards and seismic codes, which were developed at European level and in the individual Member States later [1-3]; they demand urgent structural interventions to be adapted to the current anti-seismic standards as well as requiring energy retrofitting to improve the quality of life of the residents. It is a problem of enormous proportions that involves public authorities, people active in the sector, all citizens, and those who work in the design of human life space [4,5]. In Italy, for example, a large number of existing buildings dates back to the 1960s and 1970s due to the fast growth of constructions after the World War II; the Italian national statistical institute (ISTAT), estimates that around two-thirds of the existing residential stock was built before 1974. Therefore, this building stock was designed before the enforcement of Law 64/1974 [6], the first and specific Italian code for earthquake-resistant buildings, which also includes a seismic classification map progressively updated over time. As a consequence, these existing buildings were designed utilizing relatively low seismic coefficients, on the basis of a simplified structural analysis. Little to 
no seismic provisions for capacity design and no critical region detailing were incorporated. The quality of the structural materials used in such structures is often questionable, and today they are also degraded by time. Moreover, the detailing practices at the time of construction (e.g., use of bent up reinforcement, improper anchorage of top, bottom steel in the beams, and use of smooth reinforcement) and both the consequences of recent seismic events in Italy and the inadequate parameters used to evaluate the seismic load during the sixties and seventies building stock's design phase present significant causes of uncertainty in their expected seismic behavior today, especially considering the Technical Regulations [7,8]. Such a complex subject must include an interdisciplinary approach capable of responding to specific technical problems while maintaining a global vision of the intervention to be prepared, combining structural requirements with specific plant engineering techniques and conferring a valuable architectural form.

As part of the retrofitting interventions for existing reinforced concrete (RC) frames, an interesting and common solution is the use of passive protection systems. Among them, base isolation and energy dissipation are the most utilized protection techniques. Base isolation systems are principally categorized in elastomeric bearings, friction systems, and rolling systems, examples of which are found in [9-15]; energy dissipation systems, depending on their dissipative behavior, can be distinguished in hysteretic metal dissipaters [16-20], dissipative braces [21-24], or devices with different dissipative behavior [25-32]. Among them, a solution that somehow invokes dissipative braces consists of dissipative frames that are coupled to the existing structure [33-35].

Based on the latest studies, a new technical solution is proposed in the present paper; it consists in an innovative system design that uses steel frames equipped with dissipaters like BRAD (buckling-restrained axial dampers) [36-38] and externally connected to the façades of an existing building [39-41]. The retrofitting method, adaptable to any RC building, is analyzed in order to investigate the capacity in improving the earthquake-resistant performance, the energy efficiency and the aesthetics of the buildings and, therefore, the quality of life for the users.

The idea of utilizing external steel frames to reduce the seismic vulnerability of buildings and their energy consumption was first conceived from a typological and structural point of view and then applied to a real case-study to perform a numerical analysis in order to check the characteristics that have been improved. The aim is to check the effectiveness of this solution in improving the existing buildings' earthquake-resistant performance, energy efficiency, and aesthetic appearance.

\section{New Retrofitting Frame System}

The biggest challenge regarding the problem of improving the eco-efficiency and seismic performance of existing RC buildings is actually the need to design a system that is adaptable to different geographical contexts, in diverse exposure conditions, applicable to buildings of different shapes, sizes, consistency, appealing to public, cooperative and/or private subjects.

A solution could be represented by a real "kit", that is an endowment, which allows to seismically retrofit and/or improve the buildings, to make them energy self-sufficient and, possibly, also produce positive energy. Finally, it should be capable of returning poor quality architectures to a new life, a new quality, a new dignity. Obviously, all this is obtained at low cost and it is easily achievable. The design approach followed an analogical process, starting from three specific needs: to create a new surface-as light and modular-on which to create a new architectural vision of the existing; to design a structure capable of stiffening the existing building and to retrofit it seismically, without compromising the "unity" of the intervention; to realize a structure able to accommodate the technological equipment necessary for the installation of systems useful for energy production.

In this paper an innovative system integrated to the existing building façades, consisting of counterweighted steel buttresses, is proposed to reduce the demand in terms of displacement (e.g., relative displacements) behaving as a ductile frame able also to stiffen the structure. In particular, the eco-efficient and anti-seismic retrofitting system proposed is an improved solution of the prototype adopted in [42] (see Figure 1) to a real multi-story building integrating BRAD-type dissipative braces. 


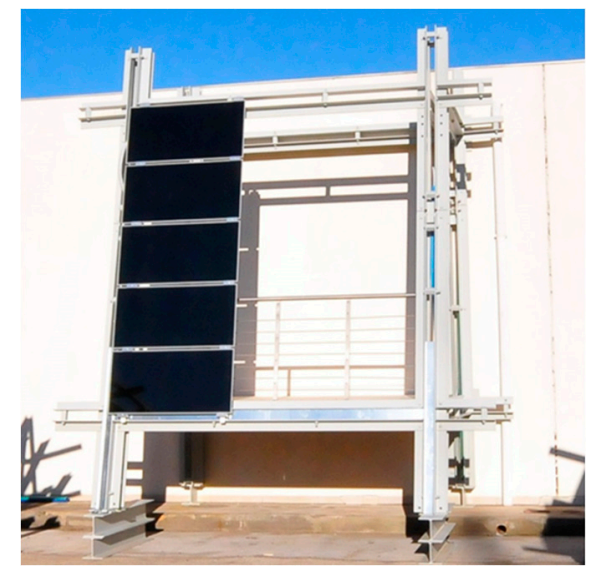

Figure 1. The grid prototype of the dissipative frame.

In [42,43], the only energy performance is analyzed through dynamic simulations, while in this paper the seismic efficiency assessment of the retrofitting system is evaluated using on-site tests in order to validate the results of the energy simulations and to investigate the seismic performance.

As previously shown [42], the technological solution is replicable as well as assembled elements (photovoltaic, solar thermal, buffer spaces, green (deciduous plant), collecting rainwater modules, shading systems, etc.) and is able to increase the surface of solar and photovoltaic (PV) panels that are generally limited to the roof of existing buildings. It has been thought to be flexible and it can be fitted to different settings of the existing buildings, the morphology of the area and the climatic conditions. Moreover, it is not invasive because it is installed externally and it does not interfere with the indoor environments, which can be utilized by the residents (Figure 2). The basic structure, given its "lightness" and modularity, in fact, gives the designer a wide possibility to choose critically the most suitable design project to give the structure a new architectural form.

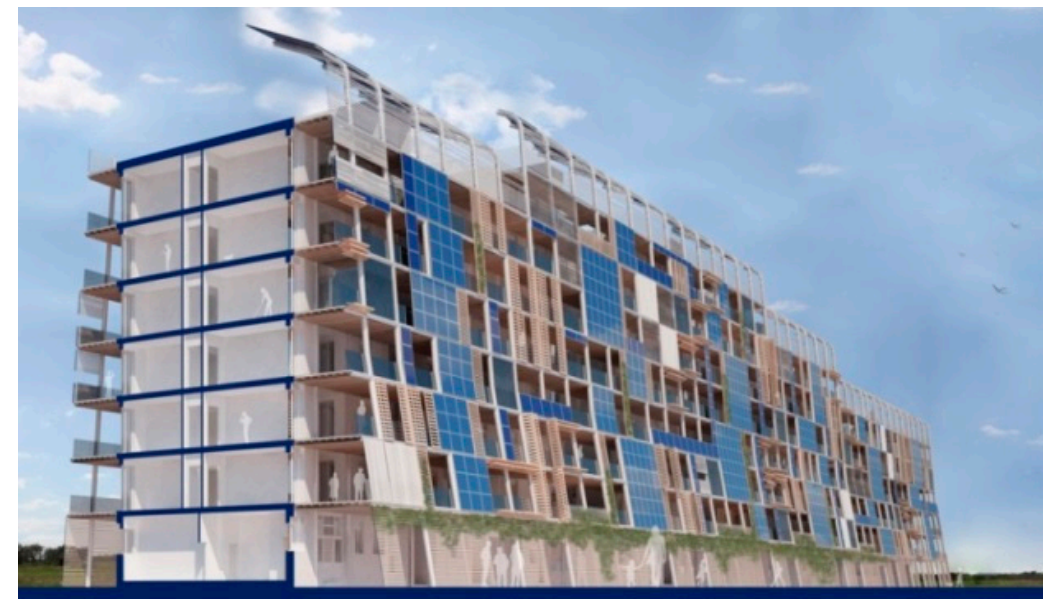

Figure 2. An example of retrofitting using the external steel frames.

The elaboration of the project idea has been conducted by a company specialized in the construction of steel structures for civil installations: "Sud Montaggi" enterprise. The relationship with such a qualified productive company was essential to solve all structural problems, both in the study and design phase and in the subsequent executive planning phase, which ended with the realization of the prototype of a full-scale module.

An "open" structure is considered, using steel beams with L-shaped profiles, suitably collaborating with each other. During the study of the executive project, some problems concerning the choice of the open profile consisting of pairs of " $L$ " steel elements also had to be solved. In fact, on the one hand, the 
choice to use an open profile guaranteed full operability and ease of management of the plant systems, and on the other hand, it required a precise study of the connection nodes. This was possible through the bolting of the elements by means of girders; thus, making the structure cohesive and allowing it to behave statically as a single structural element.

The single structural element is thus composed of the combination of four steel profiles, placed with the concave part towards the outside, to form a cross, hollow inside, and with the web exposed (see Figure 1). The collaboration between the profiles is guaranteed by the bolting between them through the use of girders, placed at a certain distance between them, and able to maintain operability between the profiles and lightness in the design performance. The structure in elevation thus consists of four columns, each made up of four steel profiles. The two columns in contact with the existing building and positioned against the columns of the reinforced concrete structure are perfectly vertical and are connected to the structure by means of steel plates placed in the structure's nodes. The two external columns are inclined and positioned in correspondence with the columns in contact with the building. The four columns in elevation are then connected to each other always using the same system formed by four L-shaped profiles, of smaller size than the profiles of the columns, and placed on the external part. The beams thus composed are positioned perpendicularly to the building, in connection between the inclined external column and the one in contact with the building in order to stiffen the structure (Figure 1). The floor slabs do not have a structural function and are composed of a main frame with IPE profile beams and a secondary frame with rectangular pipes and simple planking to close the system. This solution allows a completely dry assembly. In the space between the existing façade and the columns and beams in contact with the structure, it will be possible to arrange the construction of a thermal coat with relative finishing of the façade. The structure thus composed is perfectly hollow and statically verified. All the elements are designed and returned to standard dimensions, capable of being industrially produced with a reduction in the production costs. By simple cutting and drilling, it is possible to define the pieces needed in the different buildings to restore. What is finally defined and produced is a real kit of steel pieces, which can be assembled with relative ease and according to different needs.

The subsequent processing phase consisted of cutting the sections, in their relative grinding and engraving, preparatory to the subsequent drilling. All the girders were created by cutting, while plates and fins were welded to create the anchor plates. Before starting the on-site operations, the individual beams and columns were assembled, verifying for each of them the alignment and the exact symmetry of the profiles. Therefore, the basic module was realized to be placed in adherence to the building; it was constituted by the first pair of columns and the relative connection beams.

Thus, the actual realization of the prototype was reached. In a first step, the anchoring plates, already connected to the base module, were fixed on a large reinforced concrete wall. Subsequently, the jutting beams connected to the first two L-shaped profiles of the inclined façade columns were bolted to it. The grid, which, in fact, constitutes the new façade, was also first assembled in the workshop, and then juxtaposed on the first pair of L-shaped profiles of the façade columns, again using the girders as spacers. Afterwards, the floor package was created, consisting of a main framework with I-beams (steel beams with I-shaped cross section) and secondary warping with tubular profiles, on which a wooden plank floor was laid. The last phase was dedicated to the assembly of an energy package, consisting of five photovoltaic panels mounted on tracks anchored to the inclined structure, and to the relative wiring inside the open profiles. The prototype was finally completed with the assembly of an iron railing and with the covering of the open profiles by means of an aluminum carter (Figure 3). 

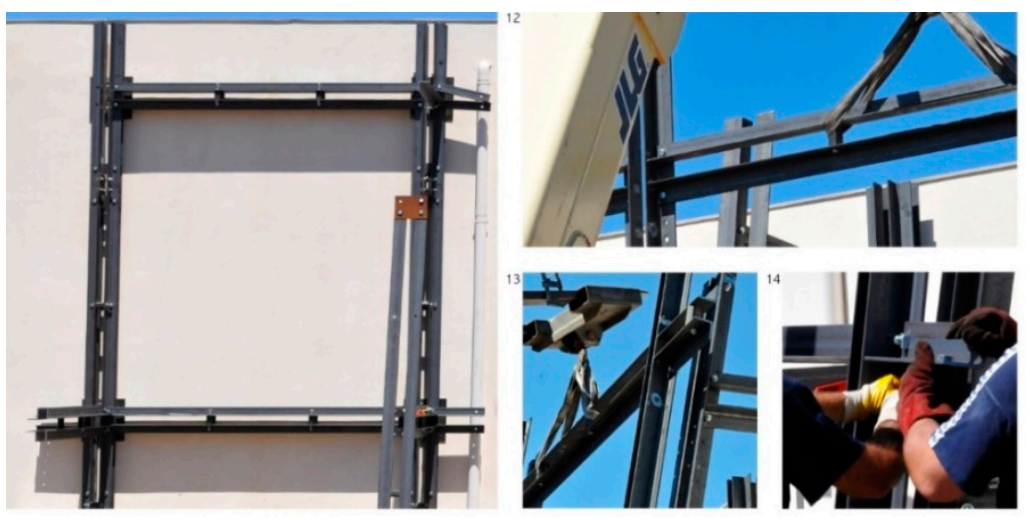

(a)
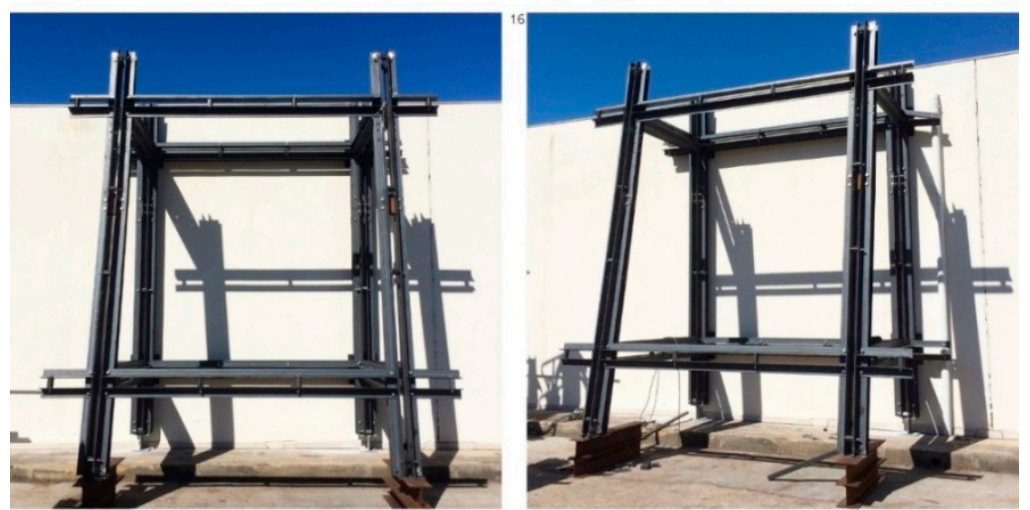

(b)
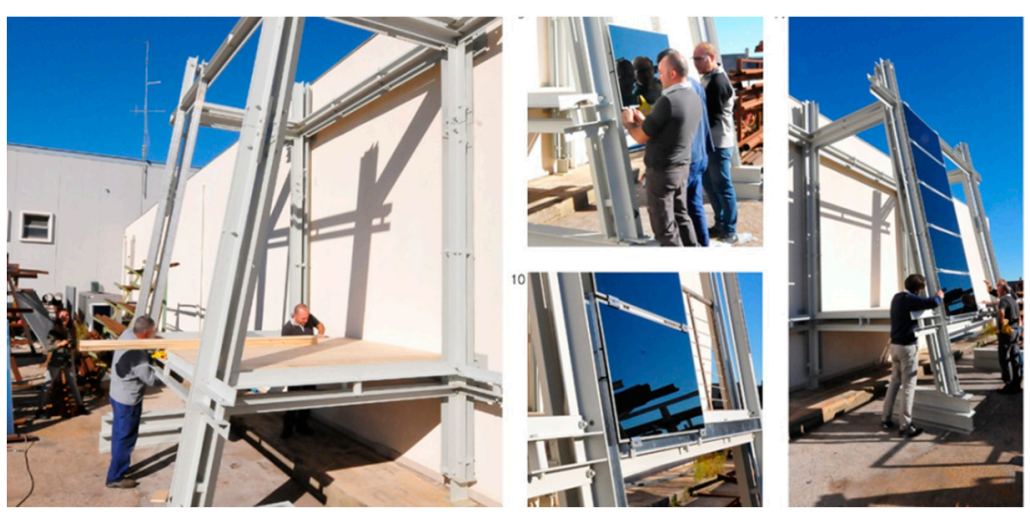

(c)

Figure 3. Construction of the prototype [42]: (a) Assembly phases of the steel frame; (b) final steel frame; and (c) thermal solar and photovoltaic (PV) panels installation.

Finally, the dissipative system composed of buckling-restrained axial dampers (BRAD) diagonal dissipators was installed in the steel grids of the external frames. The axial hysteretic dissipators with inhibit instability of the BRAD ${ }^{\circledR}$ series are non-linear anti-seismic devices whose behavior essentially depends on the displacement. They are particularly suitable for use as dissipative bracing for the seismic protection by energy dissipation of steel frame buildings. The inclusion of these devices within the structural meshes leads to an increase in the dissipative capacity of the structure, and therefore significantly improves its response to earthquakes (Figure 4). Until yielding is achieved, BRAD ${ }^{\circledR}$ 
dissipaters increase the stiffness of the structure, an effect that can be particularly useful for complying with the code requirements limiting the inter-floor displacement to the limit damage state.

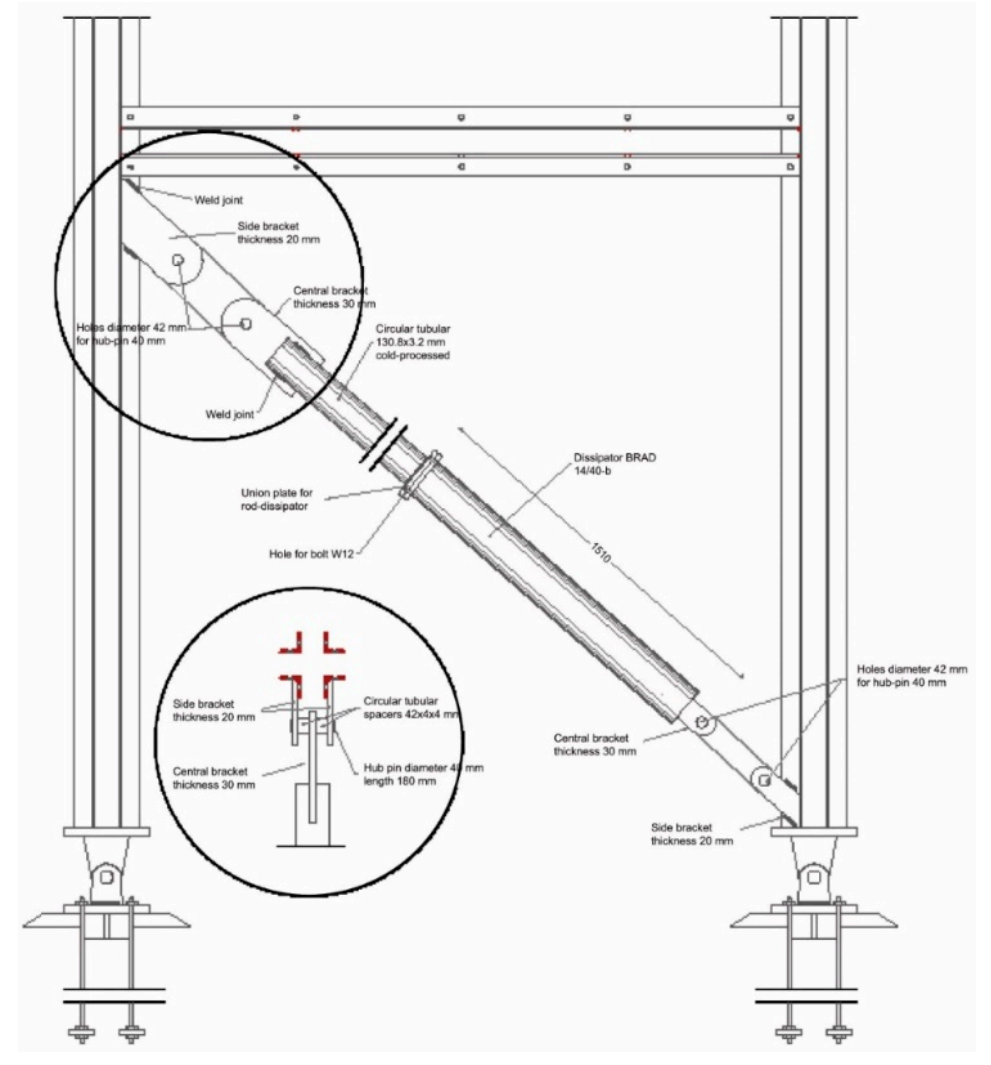

Figure 4. Buckling-restrained axial dampers (BRAD) 14/40-b dissipater inside the frame grid.

BRADs ${ }^{\circledR}$ consist of a cylinder body, an anchor flange, and an anchoring structure (Figure 5). The anchor flange is rigidly connected to the cylinder body, while the anchoring structure can undergo a relative axial displacement with respect to itself. The cylinder body is constituted by

- an inner metallic core, a part of which is designed to dissipate energy in the plastic field;

- $\quad$ a steel tube that encloses it; and

- a filling in cement mortar, whose purpose is to prevent the inner core becomes unstable.

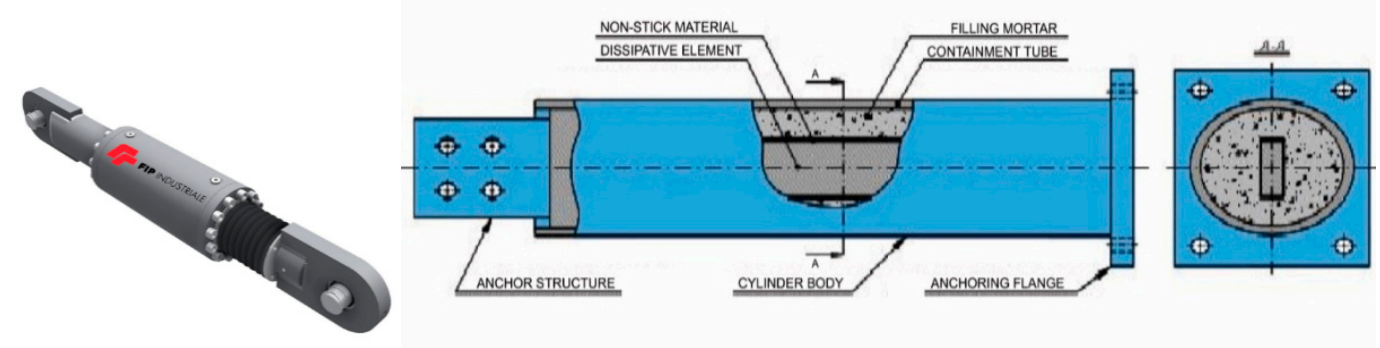

Figure 5. Detail of a BRAD ${ }^{\circledR}$ device.

A layer of release material is interposed between the mortar and the inner core, in order to prevent the transmission of tangential stresses between the two components; thus, allowing the inner core to lengthen and shorten freely, dissipating energy both in the traction and in the compression phase. The lateral confinement of this dissipative element, conferred by the cement mortar and the steel cylinder, 
makes it possible to prevent the instability of the core during the compression phase, and therefore to obtain wide and stable hysteretic cycles (Figure 6).

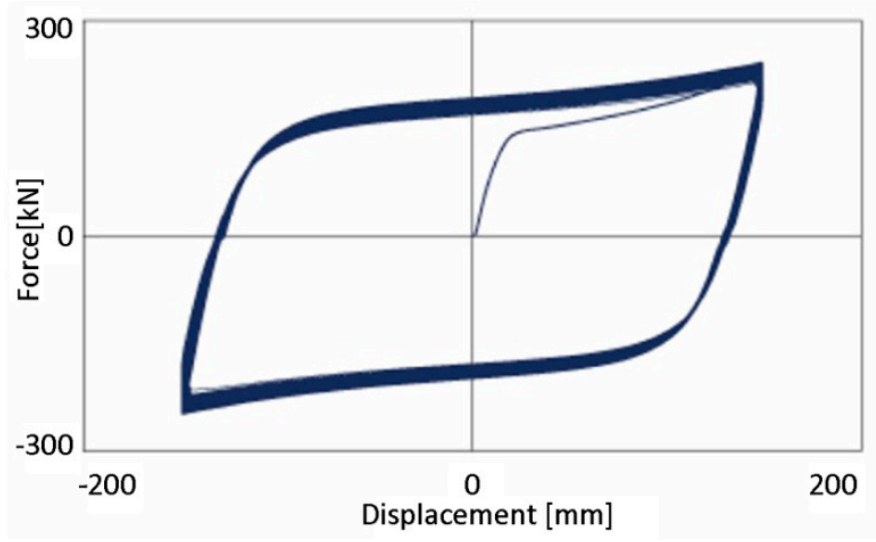

Figure 6. Experimental hysteretic cycles of a steel hysteretic dissipater with BRAD.

BRAD-type devices, subjected to cyclic loads, are characterized by a wide and stable hysteretic behavior even after many cycles, independent of temperature and speed, with a compressive strength close to the tensile one. The activation of these devices occurs when a predetermined stress value is reached and, for exceptional actions, the input energy is largely absorbed by the dissipaters.

The energy dissipation through the yielding of BRAD-type devices involves numerous advantages:

- the energy dissipation is located in a device that can be used as "fuse", as it is easily replaceable, maintaining the main structure in the elastic field and therefore free from damage; and

- the yield of BRAD devices does not affect the resistance to vertical loads of the structural system.

Furthermore, these devices, made with traditional materials, require little maintenance, and therefore represent, even from an economic point of view, a valid solution to dissipate energy. However, these elements provide a concentrated force at the connection that must be considered when checking the structures that they are connected to.

Once the assembly of the structure has been completed, it is possible to proceed with the installation of the vertical closing systems, through the positioning of opaque or permeable screens, and the positioning of selected energy packages. The cavities allow the systems placed on the façade to be connected directly to the individual housing units, without having to contemplate any external passage of pipes and electrical connections. It will be possible to have access to domestic hot water systems in and out, connected to the solar thermal panels; electrical connections with photovoltaic modules; passage of cables for further technological equipment such as, for example, optical fibers, pipes for the recycling of rainwater, and gray water. Furthermore, in case of future new technological developments, it will be possible to intervene directly on the plants with great ease and at very low costs. All the cavities that will house the plants can be suitably closed with the use of carters. The choice of vertical closing systems responds to both energy needs and architectural choices.

\section{Energy and Seismic Retrofitting Building}

\subsection{Case-Study Description}

The building case-study belongs to a typology recurrent in the popular residential construction (PRC) of Santa Rita district, in the suburbs of the town of Bari (Italy). The building is composed of modules divided by structural joints; the corner module of building " $\mathrm{D}$ " was examined (see Figure 7). The building dates back to 1981 and was built in an area not classified as a seismic one at that time. It is a RC framed structure with $11.05 \times 44.4 \mathrm{~m}$ dimensions in plan and eight levels, all built over 
the ground (Figure 8). The façades of the buildings are coated with brick hollow walls. The plan section is composed by two structurally symmetrical parts. For each of these two halves, the staircase is centrally located on one of the longer sides. The characteristics (material properties, dimensions, and reinforcement) of the structural elements have been evaluated on the basis of the current codes at that time and the common use manuals.
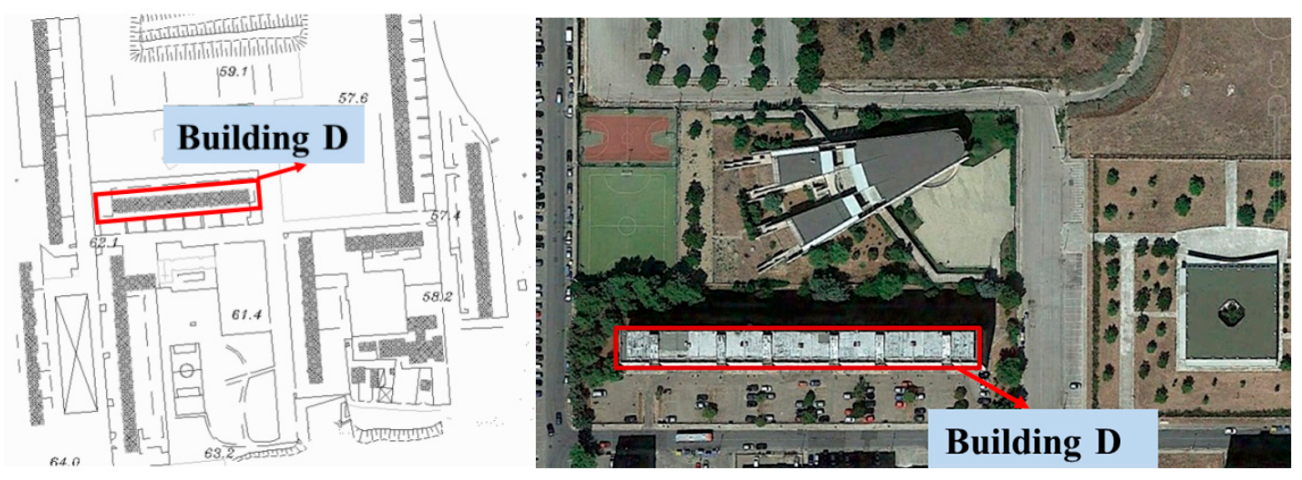

Figure 7. Positioning of Building D in Santa Rita district, in the neighborhood of Bari, Italy.
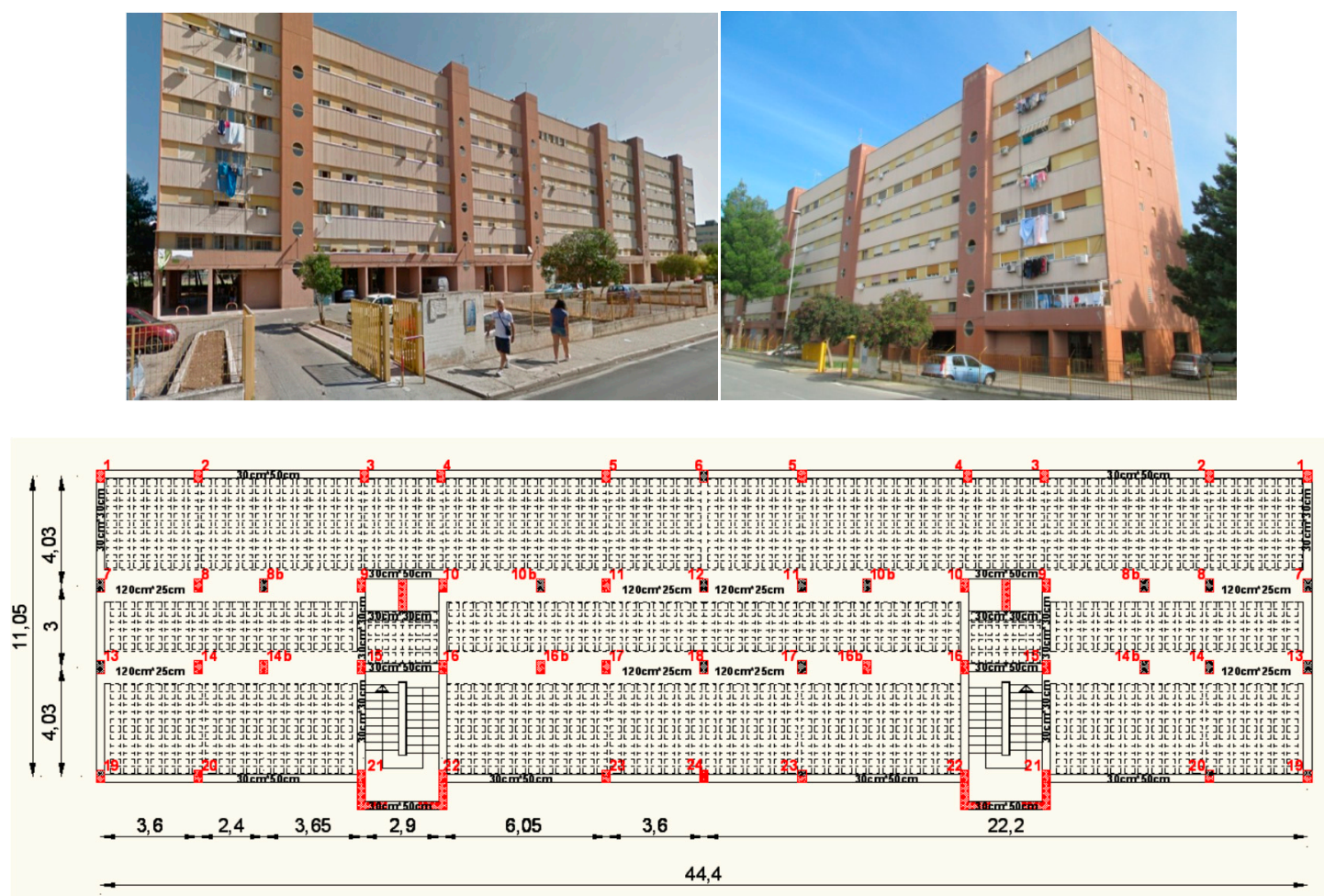

Figure 8. Building to retrofit with external steel frames (Santa Rita district, Bari, Italy).

Type Rck 250 class concrete and improved grip steel [44] have been supposed as being utilized in the original design, following the old admissible stress method. The floors are made with a mixed structure of reinforced concrete or pre-stressed concrete and bricks, while the roof is an RC hollow-tile floor with low thermal insulation. The single-glazed windows have galvanized steel frames.

\subsection{Energy Refurbishment of Existing Building: Case-Study Analysis}

Generally, the energetic efficiency of buildings in use is not consistent with current standards and with the users' expectations. In particular, the building stocks for social housing, realized until the last decade in all Europe, require specific energetic refurbishment. In southern Italy, the main 
weaknesses of social housing are the lack of sun shields that causes overheating, poor ventilation causing excess of moisture, high transmittance of the walls causing problem of condensation, and obsolete heating systems.

The demolition and the reconstruction of existing buildings are not always the best solution because they involve the temporary movement of the inhabitants and this is not always possible. Therefore, minimal invasive procedures are preferred, such as the construction of a thermal insulation of the walls or the replacement of obsolete boilers, even if they are often insufficient to achieve the high performances of the building-plant system required by law.

From an energy point of view, the proposed solution increases the surface area for solar energy capture in the existing buildings, which is usually limited to the roof area, so that it is possible to integrate renewable energies (solar and photovoltaic) and passive modules (vegetation shelters, buffer space, and water collectors).

The retrofitting system was tested by a dynamic simulation through Design Builder (DB) software [45] in order to check the capacity in energy production and energy saving. The results of the numerical simulation are shown in [43].

As reported in [43], first an abacus was created in order to summarize the energy performance of the active and passive systems employed and to have a first immediate dimensioning of the benefits represented by the kit. Then, these results were used for the simulation of a kit applied to an existing building with the proposal of different retrofitting methods in order to evaluate the best energy benefits. The energy performances of the kit were evaluated on the selected case study.

Bari is located in a Mediterranean area and its climate is characterized by hot summers and mild winters, with moderate temperatures. According to the Typical Meteorological Year (TMY) generated by Meteotest [46], the maximum Dry Bulb temperature is $36.6^{\circ} \mathrm{C}$ on $21 \mathrm{July}$ and the minimum is $0.7^{\circ} \mathrm{C}$ on 12 January.

The energy consumption was simulated for the present configuration of the building without insulation and with obsolete boilers and for three different hypotheses of refurbishment:

(I) external insulation ( $0.09 \mathrm{~m}$ of polystyrene),

(II) external insulation and replacement of the obsolete gas boilers $\left(\eta_{100 \%}=88.2 \%\right)$ with high-efficient gas boilers $\left(\eta_{100 \%}=98 \%\right)$, and

(III) external insulation, a geothermal heat pump and electrical boilers for hot water production.

Table 1 shows the results of the simulations in terms of energy need and consumption for cooling and heating [47].

Table 1. Energy need for heating (EH) and cooling (EC) and consumption (gas G; electricity El) for Heating and Domestic Hot Water (DHW) in all the configurations.

\begin{tabular}{|c|c|c|c|c|c|}
\hline Config. & \multicolumn{2}{|l|}{$\mathrm{E}_{\mathrm{H}}$} & \multicolumn{2}{|l|}{$\mathrm{G}_{\mathrm{H}}$} & $\mathrm{G}_{\mathrm{DHW}}$ \\
\hline Current & \multicolumn{2}{|c|}{$\begin{array}{l}61,839 \mathrm{kWh} \\
\left(58.89 \mathrm{kWh} \mathrm{m}^{-2} \text { year }^{-1}\right)\end{array}$} & \multicolumn{2}{|c|}{$\begin{array}{l}70,727 \mathrm{kWh} \\
\left(67.36 \mathrm{kWh} \mathrm{m}^{-2} \text { year }^{-1}\right)\end{array}$} & $\begin{array}{l}\text { 107,371 kWh } \\
\left(102.26 \mathrm{kWh} \mathrm{m}^{-2} \text { year }^{-1}\right)\end{array}$ \\
\hline Hyp. I & \multicolumn{2}{|c|}{$\begin{array}{l}46,517 \mathrm{kWh} \\
\left(44.30 \mathrm{kWh} \mathrm{m}^{-2} \text { year }^{-1}\right)\end{array}$} & \multicolumn{2}{|c|}{$\begin{array}{l}52,860 \mathrm{kWh} \\
\left(50.34 \mathrm{kWh} \mathrm{m}^{-2} \text { year }^{-1}\right)\end{array}$} & $\begin{array}{l}\text { 107,371 kWh } \\
\left(102.26 \mathrm{kWh} \mathrm{m}^{-2} \text { year }^{-1}\right)\end{array}$ \\
\hline Hyp. II & \multicolumn{2}{|c|}{$\begin{array}{l}46,491 \mathrm{kWh} \\
\left(44.28 \mathrm{kWh} \mathrm{m}^{-2} \text { year }^{-1}\right)\end{array}$} & \multicolumn{2}{|c|}{$\begin{array}{l}\left.47,440 \mathrm{kWh}^{-2} \mathrm{year}^{-1}\right) \\
\left(45.18 \mathrm{kWh} \mathrm{m}^{-2}\right.\end{array}$} & $\begin{array}{l}\text { 96,415 kWh } \\
\left(91.82 \mathrm{kWh} \mathrm{m}^{-2} \text { year }^{-1}\right)\end{array}$ \\
\hline \multirow{2}{*}{ Hyp. III } & $\mathrm{E}_{\mathrm{H}}$ & $E_{C}$ & $\mathrm{El}_{\mathrm{H}}$ & $\mathrm{El}_{\mathrm{C}}$ & $\mathrm{El}_{\mathrm{DHW}}$ \\
\hline & $\begin{array}{l}44,244 \mathrm{kWh} \\
\left(42.14 \mathrm{kWh} \mathrm{m}^{-2}\right. \\
\left.\text { year }^{-1}\right)\end{array}$ & $\begin{array}{l}27,556 \mathrm{kWh} \\
\left(26.24 \mathrm{kWh} \mathrm{m}^{-2}\right. \\
\left.\text { year }^{-1}\right)\end{array}$ & $\begin{array}{l}11,432 \mathrm{kWh} \\
\left(10.89 \mathrm{kWh} \mathrm{m}^{-2}\right. \\
\left.\text { year }^{-1}\right)\end{array}$ & $\begin{array}{l}9906 \mathrm{kWh} \\
\left(9.43 \mathrm{kWh} \mathrm{m}^{-2}\right. \\
\left.\text { year }^{-1}\right)\end{array}$ & $\begin{array}{l}86,483 \mathrm{kWh} \\
\left(82.36 \mathrm{kWh} \mathrm{m}^{-2} \text { year }^{-1}\right)\end{array}$ \\
\hline
\end{tabular}

The results of the simulations demonstrate that the refurbishment, obviously, improves the energy performance of the building, with a reduction of the energy needs compared to the present state. Then 
five kits, three with solar thermal modules and two with PV modules (Figure 9), were installed on the buildings.
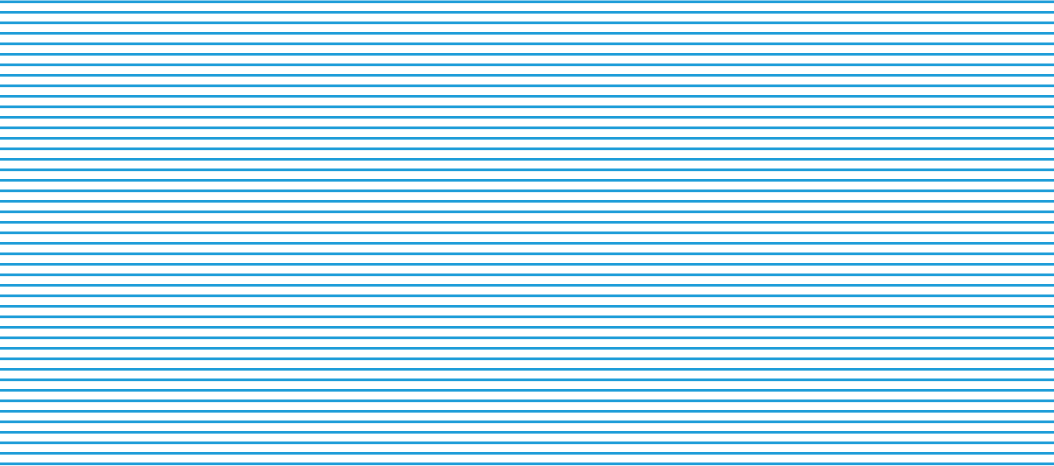

Figure 9. Arrangement of the five kits (PV modules in blue and thermal solar modules in orange).

This configuration produces $16,966 \mathrm{kWh}$ electrical per year and 55,309 $\mathrm{kWh}$ thermal per year.

The main results of [44] show that, by means of the dynamic simulation, the energy performance of the building has been calculated with the new applied system (Figure 10).

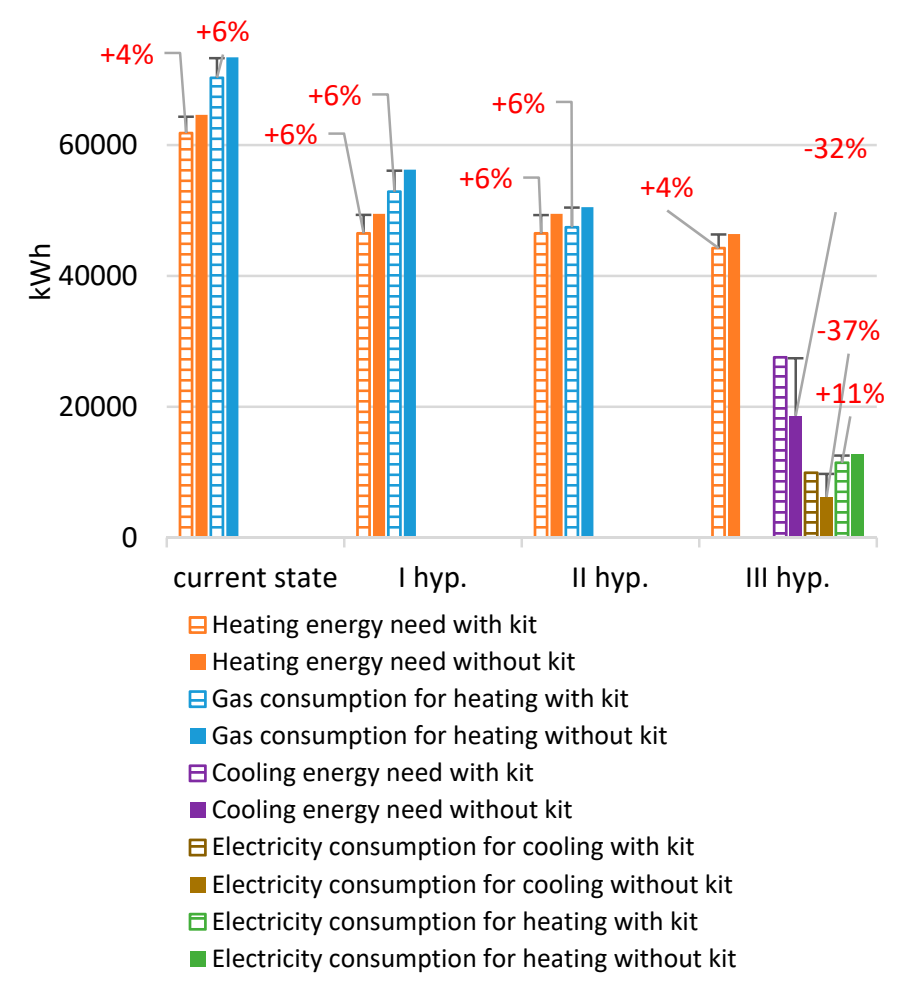

Figure 10. Energy need and consumption, with and without the kit [kWh].

Outputs show that the kit causes shading in all the considered cases and that it leads to an increase of the heating requirements and a consequent increase in the consumption of gas in winter.In all the cases, the consumption of gas for heating increases by $6 \%$. On the contrary, the shadowing effect is positive in Hypothesis III (exterior insulation and geothermal heat pump) where the electricity consumption for cooling is reduced by $37 \%$. There is a considerable reduction of energy consumption, by analyzing the annual results of the simulations. The solar modules allowthe coverage of half of the annual consumption for the production of hot water: about $51 \%$ in the case of the simple application of the system without any redevelopment, and up to $57 \%$ in the case of the external insulation and 
the replacement of the low efficiency boilers. Moreover, in three out of the four scenarios considered (present configuration and hypotheses I and II), the energy produced by the PV modules is sufficient to cover all consumption arising from lighting. In the last case (with heat pump), the solar system covers up to $64 \%$ of the annual consumption for hot water produced for example by electric water boilers, while the PV meets $100 \%$ of the energy consumption of the heat pump for heating and cooling.

The dynamic simulations allow to compare and analyze the results and to confirm the improvement of energy efficiency of the building when the refurbishment is more efficient.

\subsection{Seismic Retrofitting System Design}

Based on the promising results of energy analysis, the steel frame adopted in [43] was equipped with dissipative bracings (Figure 4) and suitable elements to improve the energy consumption. The retrofitting system was designed and analysed for the specific case study. Dissipative braces were distributed over the entire height of the building by trying to distribute their stiffness in $X$ and $Y$ directions, in proportion to their respective displacements, with the aim of linearizing the deformation and regularizing the structure. Moreover, given that the existing structure reaches the ultimate condition almost without drawing on its own plastic resources, it was considered appropriate to neglect the dissipative contribution of the existing structure in sizing the dissipative braces while maintaining high precision.

The design of the braces was performed by fixing as objective displacement $\mathrm{D}^{*}$ the ultimate displacement $\mathrm{Du}$ of the building in both directions $\left(\mathrm{D}^{*}=\mathrm{Du}=78 \mathrm{~mm}\right.$ in $\mathrm{X}$ direction; $\mathrm{D}^{*}=\mathrm{Du}=67 \mathrm{~mm}$ in $\mathrm{Y}$ direction). The application of the procedure was conducted since the first iterations achieved a sizing that were compatible with the desired performance levels. From the analyses carried out in both $X$ and $Y$ directions it was necessary to use four BRAD 14/40-b dissipaters coupled with $139.9 \times 3.2 \mathrm{~mm}$ circular tubes at each level and for each direction. The layout of the devices is shown in Figure 11.

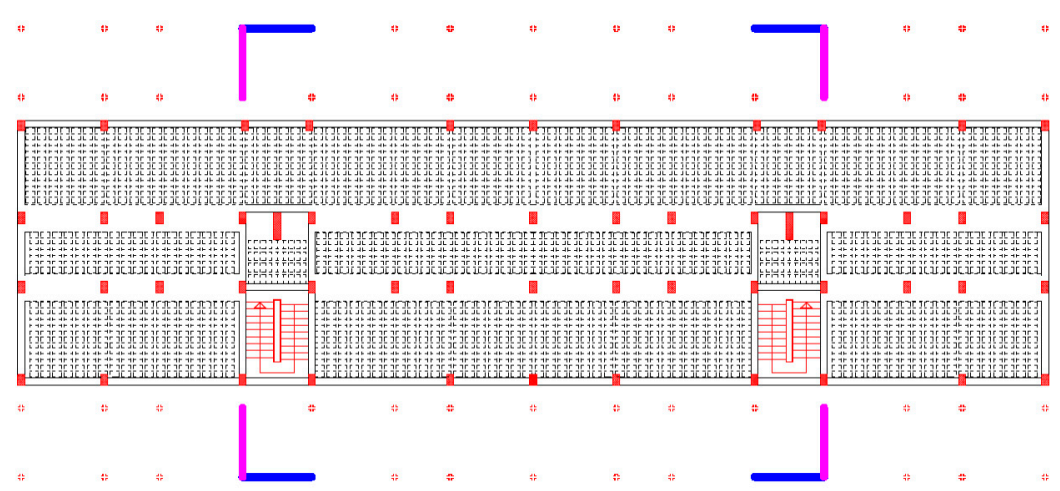

Figure 11. Plan view of the building and position of the dissipative braces (in bold).

Finite Element (FE) models of the existing building (with and without retrofitting system) were developed to predict the seismic performance using the commercial software STRAUS 7 [48]. In the three-dimensional model (Figure 12a) without the retrofitting system, the reinforced concrete beams and columns were modelled as frame-type elements; the concrete walls were modelled as shell type elements. In order to investigate the effectiveness of the designed retrofitting system (Figure 12b), the complete three-dimensional model of the retrofitted structure was developed (Figure 12c). Non-linear analysis of the building frames, subjected to gravity loads and a live load equal to $200 \mathrm{~kg} / \mathrm{cm}^{2}$, were carried out. The capacity curves (in directions $\mathrm{X}$ and $\mathrm{Y}$ ) of the existing building obtained by a push-over analysis were compared to the capacity curves of the structure equipped with dissipative braces system. 


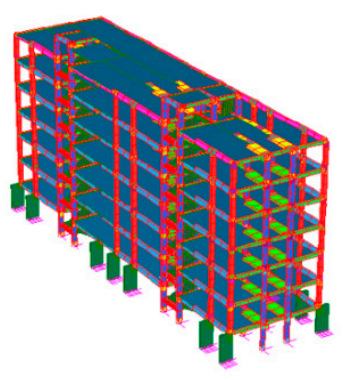

(a)

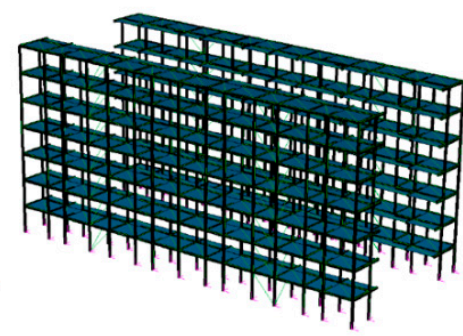

(b)

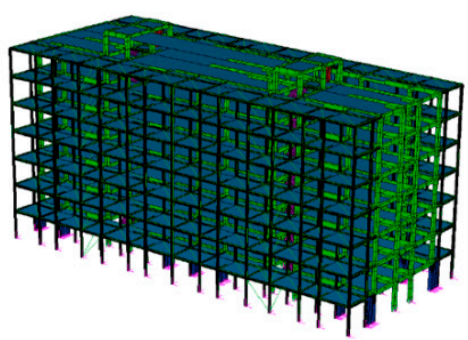

(c)

Figure 12. (a) FE model of the structure without the retrofitting system; (b) dissipative retrofitting system; and (c) FE model of the retrofitted structure.

\section{Analysis Results}

The FEM analysis conducted on the building case-study has allowed us to determine the overall capacity of the structure that depends on the strength and deformation capacities of the individual components. After the seismic strengthening, capacity curves obtained from pushover analysis of the building were found to meet the displacement demand.

In particular, adopting the retrofitting devices, a performance point (PP) of the structure equipped with dissipative braces was provided, with a top displacement of $64.3 \mathrm{~mm}$, a base shear equal to $2305 \mathrm{kN}$ in $\mathrm{Y}$ direction, and an equivalent damping of $12.86 \%$ (opposite to a performance point of the existing structure characterized by a top displacement of $109.5 \mathrm{~mm}$ and a base shear of $2430 \mathrm{kN}$ ) (Figure 13).

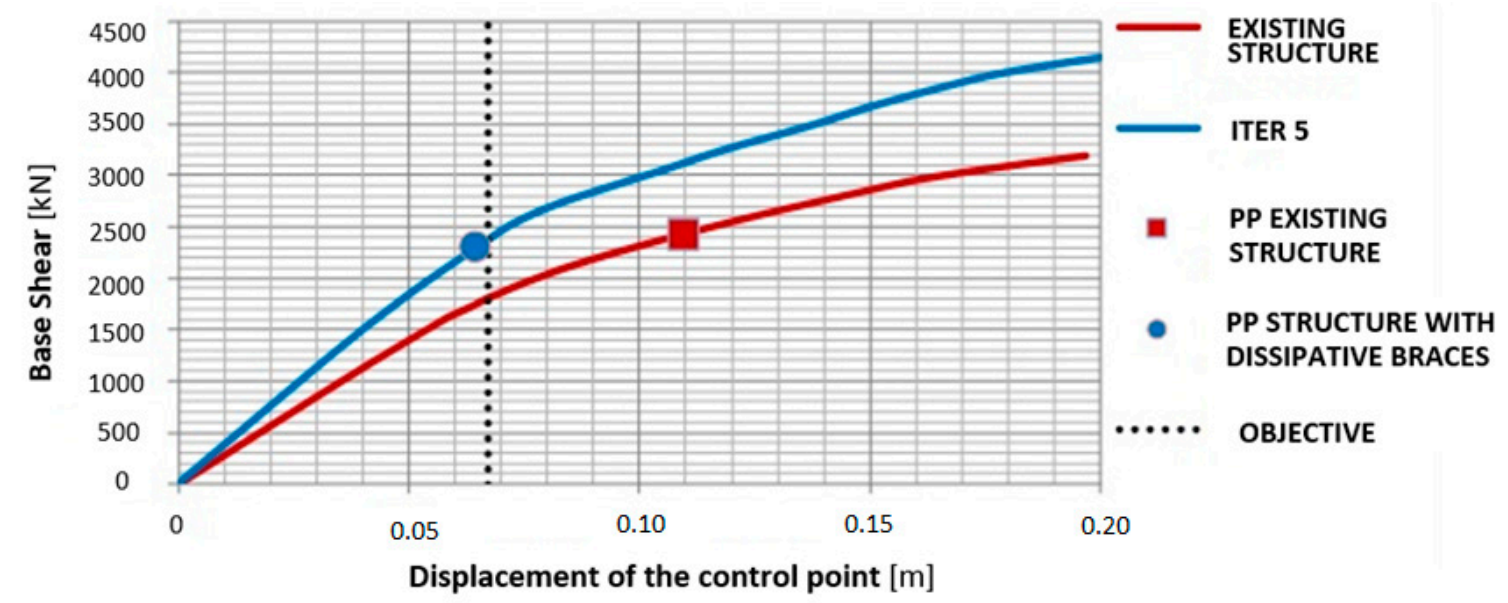

Figure 13. Capacity curves in $\mathrm{Y}$ direction after retrofitting, with the relative performance points (PP) and objective displacement.

In $\mathrm{X}$ direction, the performance point shows a top displacement of $66.9 \mathrm{~mm}$ and a base shear equal to $2510 \mathrm{kN}$, with an equivalent damping of $11.92 \%$ (opposite to a performance point of the existing structure characterized by a top displacement equal to $105.9 \mathrm{~mm}$ and a base shear of $2760 \mathrm{kN}$ ) (Figure 14). ITER5 and ITER4 in Figures 13 and 14, respectively, refer to the corresponding iteration step in the pushover analysis that better converges to the capacity curve of the structure protected with dissipating braces. 


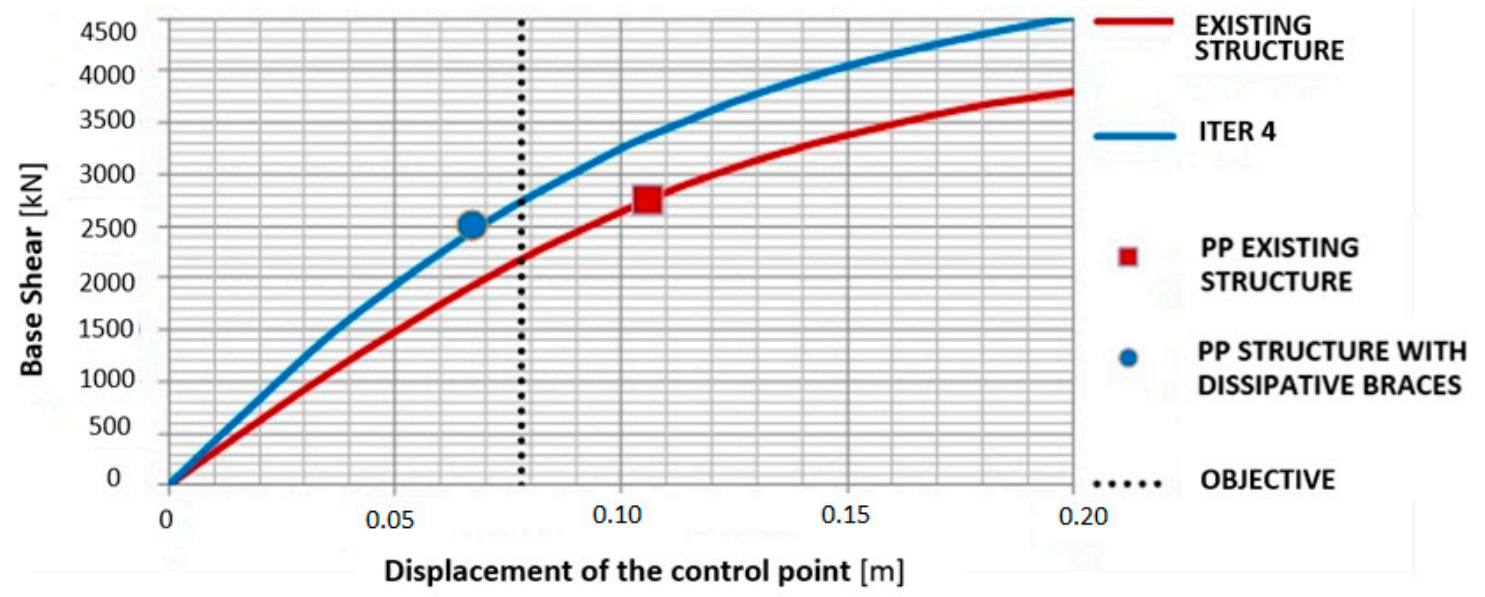

Figure 14. Capacity curves in $\mathrm{X}$ direction after retrofitting, with the relative performance points (PP) and objective displacement.

From the results so obtained, it is possible to notice a reduction in the demand both in terms of displacement and in terms of acceleration and therefore in terms of the base shear in both directions, with the consequent achievement of the predetermined objective. In particular, the retrofitting device reduces the building top displacement in $\mathrm{Y}$ direction by about $41.3 \%$, in $\mathrm{X}$ direction by about $36.8 \%$, at the building base shear in $Y$ direction by about $5.1 \%$, and in $X$ direction by about $9.1 \%$, respectively.

Through the analysis it is shown that the BRAD retrofitting system shows some advantages in terms of reduction of the displacement capacity. Accordingly, the innovative retrofitting strategy with braces provides a more robust nonlinear behavior of the existing structure improving the seismic performance. The efficacy data of this study are consistent with the increase of the safety factor (ratio between the capacity displacement and the target displacement) presented in [36]. For the case-study the safety factors in $\mathrm{Y}$ and $\mathrm{X}$ directions determined with the nonlinear analysis are equal to 1.70 and 1.58 , respectively.

\section{Conclusions}

The present paper proposes a new retrofitting solution for existing buildings, which were not designed to withstand high seismic forces, nor to have a good energy performance in terms of reduction of the energy consumption.

The solution here adopted is based on the use of dissipative steel frames coupled to the existing structure in order to improve its anti-seismic strength, energy efficiency, and aesthetic profile.

From both the seismic protection and the energy consumption reduction points of view the results of the present research are very encouraging; the system allows existing building to achieve the target of positive energy building, while the dissipative bracings inserted in the girders of the added steel frames produce a remarkable anti-seismic improvement, as shown by the obtained results and the reduction in terms of top displacement in $Y$ direction by about $41.3 \%$ and in $X$ direction by about $36.8 \%$.

Finally, this type of intervention has a high modularity that makes it adaptable to any architectural and energy requirements, while the possibility of dry mounting, with welding operations concentrated only on a few elements, determines a reduction of the construction time.

It must be underlined that the present research is continuing with the construction of a prototype in order to test the real performance and to validate the simulation results. In addition, the potential of this system in the structural upgrading of the building will be investigated, with the aim to provide the market with a multifunctional and prefabricated system for a modern retrofit of existing buildings.

Author Contributions: Conceptualization, D.F.; data curation, F.R. and M.L.; funding acquisition, F.R.; investigation, M.F.S.; validation, M.L.; and writing-original draft, D.F. and F.R. All authors have read and agreed to the published version of the manuscript. 
Funding: This research received no external funding.

Acknowledgments: "Sud Montaggi s.r.l." is acknowledged for providing the executive drawings and images relating to the prototype realization.

Conflicts of Interest: The authors declare no conflict of interest.

\section{Abbreviations}

$\begin{array}{ll}\text { BRAD } & \text { Buckling-Restrained Axial Dampers } \\ \text { DB } & \text { Design Builder } \\ \text { FE } & \text { Finite Element } \\ \text { PRC } & \text { Popular Residential Construction } \\ \text { PP } & \text { Performance Point } \\ \text { PV } & \text { Photovoltaic } \\ \text { RC } & \text { Reinforced Concrete }\end{array}$

\section{References}

1. European Standards (EN). Eurocode 2: Design of Concrete Structures EN1992-1-1. Available online: https://www.phd.eng.br/wp-content/uploads/2015/12/en.1992.1.1.2004.pdf (accessed on 30 June 2020).

2. Directive 2010/31/EU of the European Parliament and of the Council of 19 May 2010 on the Energy Performance of Buildings. Available online: https:/eur-lex.europa.eu/legal-content/EN/TXT/PDF/?uri= CELEX:32010L0031\&from=en (accessed on 30 June 2020).

3. Building Directive 2002/91/EC of the European Parliament and of the Council of 16 December 2002 on the Energy Performance of Buildings C. Available online: https://eur-lex.europa.eu/LexUriServ/LexUriServ.do? uri=OJ:L:2003:001:0065:0071:EN:PDF (accessed on 30 June 2020).

4. La Greca, P.; Margani, G. Seismic and Energy Renovation Measures for Sustainable Cities: A Critical Analysis of the Italian Scenario. Sustainability 2018, 10, 254. [CrossRef]

5. Mangold, M.; Österbring, M.; Wallbaum, H.; Thuvander, L.; Femenias, P. Socio-economic impact of renovation and energy retrofitting of the Gothenburg building stock. Energy Build. 2016, 123, 41-49. [CrossRef]

6. Italian Law n. 64/1974. Provvedimenti per le Costruzioni con Particolari Prescrizioni per le Zone Sismiche; Gazzetta Ufficiale della Repubblica Italiana: Rome, Italy, 1974. n. 76 del 2.2.1974. Available online: http://people.dicea.unifi.it/gianni.bartoli/normative/L_02.02.74_n.64.pdf (accessed on 30 June 2020). (In Italian).

7. Italian Ministry of Public Works MIT: Ministry Decree D.M. 17th January 2018. Technical Regulations for Constructions Italian Lawor Aggiornamento Delle « Norme Tecniche per le Costruzioni ». Supplemento ordinario n. 8 alla Gazzetta Ufficiale della Repubblica Italiana n. 42 of 20-2-2018; Rome, Italy. Available online: https://www.gazzettaufficiale.it/eli/id/2018/2/20/18A00716/sg (accessed on 30 June 2020). (In Italian).

8. Italian Ministry of Public Works: Circolare n.7 21st January 2019. Commentary on Technical Regulations for Constructionsor Istruzioni per L'applicazione Dell' «Aggiornamento Delle "Norme Tecniche per le Costruzioni» di cui al Decreto Ministeriale 17 Gennaio 2018". Gazzetta Ufficiale n. 35 of 11-02-2019; Rome, Italy. Available online: https://www.gazzettaufficiale.it/eli/id/2019/02/11/19A00855/sg (accessed on 30 June 2020). (In Italian).

9. Ordoñez, D.; Foti, D.; Bozzo, L.M. Comparative Study of the Inelastic Structural Response of Base Isolated Buildings. Earthq. Eng. Struct. Dyn. 1998, 32, 151-164. [CrossRef]

10. Foti, D.; Catalan Goni, A.; Vacca, S. On the dynamic response of rolling base isolation systems. Struct. Control Health Monit. 2013, 20, 639-648. [CrossRef]

11. Menga, N.; Foti, D.; Carbone, G. Viscoelastic frictional properties of rubber-layer roller bearings (RLRB) seismic isolators. Meccanica 2017, 52, 2807-2817. [CrossRef]

12. Shahabi, A.; Zamani Ahari, G.; Barghian, M. Base Isolation Systems-A State of the Art Review According to Their Mechanism. J. Rehabil. Civ. Eng. 2020, 8, 37-61. [CrossRef]

13. Harvey, P.S., Jr.; Kelly, K.C. A review of rolling-type seismic isolation: Historical development and future directions. Eng. Struct. 2016, 125, 521-531. [CrossRef]

14. Quaglini, V.; Gandelli, E.; Dubini, P. Experimental investigation of the re-centring capability of curved surface sliders. Struct. Control Health Monit. 2017, 24, e1870. [CrossRef] 
15. Sorace, S.; Terenzi, G. Seismic performance assessment and base isolated floor-protection of statues exhibited in museum halls. Bull. Earthq. Eng. 2015, 13, 1873-1892. [CrossRef]

16. Foti, D.; Diaferio, M.; Nobile, R. Optimal Design of a New Seismic Passive Protection Device Made in Aluminium and Steel. Int. J. Struct. Eng. Mech. 2010, 35, 119-122. [CrossRef]

17. Foti, D.; Diaferio, M.; Nobile, R. Dynamic Behavior of New Aluminum-Steel Energy Dissipating Devices. Struct. Cont. Health Monit. 2013, 20, 1106-1119. [CrossRef]

18. Nuzzo, I.; Losanno, D.; Caterino, N.; Serino, G.; Rotondo, L.M.B. Experimental and analytical characterization of steel shear links for seismic energy dissipation. Eng. Struct. 2018, 172, 405-418. [CrossRef]

19. Wang, C.L.; Liu, Y.; Zhou, L. Experimental and numerical studies on hysteretic behavior of all-steel bamboo-shaped energy dissipaters. Eng. Struct. 2018, 165, 38-49. [CrossRef]

20. Ponzo, F.C.; Di Cesare, A.; Lamarucciola, N.; Nigro, D. Testing requirements of hysteretic energy dissipating devices according to italian seismic code. In Proceedings of the COMPDYN 2019, 7th ECCOMAS Thematic Conference on Computational Methods in Structural Dynamics and Earthquake, Crete, Greece, 24-26 June 2019.

21. Palermo, M.; Silvestri, S.; Gasparini, G.; Trombetti, T. Crescent shaped braces for the seismic design of building structures. Mater. Struct. 2015, 48, 1485-1502. [CrossRef]

22. López-Almansa, F.; Castro-Medin, J.C.; Oller, S. A numerical model of the structural behavior of buckling-restrained braces. Eng. Struct. 2012, 41, 108-117. [CrossRef]

23. Qu, B.; Liu, X.; Hou, H.; Qiu, C.; Hu, D. Testing of buckling-restrained braces with replaceable steel angle fuses. J. Struct. Eng. 2018, 144, 04018001. [CrossRef]

24. Lin, P.-C.; Tsai, K.-C.; Chang, C.-A.; Hsiao, Y.-Y.; Wu, A.-C. Seismic design and testing of buckling-restrained braces with a thin profile. Earthq. Eng. Struct. Dyn. 2016, 45, 339-358. [CrossRef]

25. Symans, M.D.; Charney, F.A.; Whittaker, A.S.; Constantinou, M.C.; Kircher, C.A.; Johnson, M.W.; McNamara, R.J. Energy dissipation systems for seismic applications: Current practice and recent developments. J. Struct. Eng. 2008, 134, 3-21. [CrossRef]

26. Kim, J.; Choi, H.; Min, K.-W. Performance-based design of added viscous dampers using capacity spectrum method. J. Earthq. Eng. 2003, 7, 1-24. [CrossRef]

27. Hong-Nan, L.; Gang, L. Experimental study of structure with "dual function" metallic dampers. Eng. Struct. 2007, 29, 1917-1928.

28. Tirca, D.; Foti, D.; Diaferio, M. Response of middle-rise steel frames with and without passive dampers to near-field ground motions. Eng. Struct. 2003, 25, 169-179. [CrossRef]

29. Chung-Che, C.; Yu-Jen, L. Post-tensioned self-centering moment connections with beam bottom flange energy dissipators. J. Construct. Steel Res. 2009, 65, 1931-1941.

30. Foti, D.; Bozzo, L.M.; Lopez-Almansa, F. Numerical Efficiency Assessment of Energy Dissipators for Seismic Protection of Buildings. Earthq. Eng. Struct. Dyn. 1998, 27, 543-556. [CrossRef]

31. Altieri, D.; Tubaldi, E.; Pratelli, E.; Dall'Asta, A. Assessment of optimal design methods of viscous dampers. Procedia Eng. 2017, 199, 1152-1157. [CrossRef]

32. Lavan, O.; Dargush, G.F. Multi-objectve evolutionary seismic design with passive energy dissipation systems. J. Earthq. Eng. 2009, 13, 758-790. [CrossRef]

33. Roia, D.; Gara, F.; Balducci, A.; Dezi, L. Dynamic tests on an existing r.c. school building retrofitted with "dissipative towers". In Proceedings of the 11th International Conference on Vibration Problems, Lisbon, Portugal, 9-12 September 2013; pp. 9-12.

34. Feroldi, F.; Marini, A.; Badiani, B.; Plizzari, G.A.; Giuriani, E.; Riva, P.; Belleri, A. Energy efficiency upgrading, architectural restyling and structural retrofit of modern buildings by means of "engineered" double skin façade. In Proceedings of the 2nd International Conference on Structures \& Architecture (ICSA2013), Guimarães, Portugal, 24-26 July 2013; pp. 1859-1866.

35. Feroldi, F.; Marini, A.; Belleri, A.; Passoni, C.; Riva, P.; Preti, M.; Giuriani, E.; Plizzari, G. Miglioramento e adeguamento sismico di edifici contemporanei mediante approccio integrato energetico, architettonico e strutturale con soluzioni a doppio involucro a minimo impatto ambientale/Sustainable seismic retrofit of modern RC buildings through an integrated struc-tural, energetic and architectural approach adopting external engineered double skin façades. Progett. Sismica 2014, 5, 2. 
36. Di Sarno, L.; Manfredi, G. Seismic retrofitting of existing RC frames with buckling restrained braces. In Proceedings of the ATC and SEI Conference on Improving the Seismic Performance of Existing Buildings and Other Structures, San Francisco, CA, USA, 9-11 December 2009; pp. 741-752.

37. Cancellara, D.; De Angelis, F. Steel braces in series with hysteretic dampers for reducing the seismic vulnerability of RC existing buildings: Assessment and retrofitting with a nonlinear model. Appl. Mech. Mater. 2012, 204-208, 2677-2689. [CrossRef]

38. Cancellara, D.; De Cicco, S.; De Angelis, F. Assessment and vulnerability reduction of under-designed existing structures: Traditional vs. innovative strategy. Comput. Struct. 2019, 221, 44-64. [CrossRef]

39. Di Turi, S.; Mastrorilli, A.; Ruggiero, F. Positive energy buildings in the regeneration of urban peripheries in the Mediterranean areas. In Proceedings of the 8th Mediterranean Congress of Heating, Ventilation and Air-Conditioning (CLIMAMED 15), Juan les Pins, France, 9-11 September 2015.

40. Takeuchi, T. Buckling-Restrained Brace: History, Design and Applications. Key Eng. Mater. 2018, 763, 50-60. [CrossRef]

41. Sadeghi, S.; Rofooei, F.R. Improving the seismic performance of diagrid structures using buckling restrained braces. J. Constr. Steel Res. 2020, 166, 105905. [CrossRef]

42. Parisi, N.; Ruggiero, F.; Bernasconi, C.; Lerario, G.V.; Maranci, A.; Moramarco, C.; Rotolo, N.; Treglia, P. Renew Urban. Edifici ad energia positiva nella rigenerazione delle periferie urbane; Arti Grafiche Favia s.r.l.: Bari, Italy, 2015; ISBN 978-88-6922-037-1. (In Italian)

43. Ruggiero, F.; Di Turi, S.; Mastrorilli, A. Study of an Integrated Retrofit System for Energy Positive Buildings in Urban Areas. Adv. Model. Anal. A 2018, 55, 136-143. [CrossRef]

44. Legge Numero 1086 del 5 Novembre 1971 “Norme per la Disciplina delle Opere di Conglomerato Cementizio Armato, Normale e Precompresso ed a Struttura Metallica". Available online: https://www.stradeanas.it/ sites/default/files/pdf/3.5.2/02\%20-\%20Legge\%205\%20novembre\%201971\%20n.\%201086.pdf (accessed on 30 June 2020). (In Italian).

45. Software Design Builder, v4.2.0.054.

46. Meteotest. Meteonorm Version 7.1. Available online: www.meteonorm.com (accessed on 30 June 2018).

47. International Organization for Standardization. Energy Performance of Buildings_Indicators for Partial EPB Requirements Related to Thermal Energy Balance and Fabric Features; ISO 52018:2017; ISO: Geneva, Switzerland, 2017.

48. STRAUSS 7, v 2.3.3, Strand 7 Pty Ltd (AUS), Sydney, Australia. 